\title{
STRATEGI PENANAMAN NASIONALISME PADA PONDOK PESANTREN (Studi Kasus Tentang Penanaman Nasionalisme pada Santri Pondok Pesantren Sunan Gunungjati Ba'alawy, Gunungpati, Semarang)
}

\author{
Asrori Arafat ${ }^{1}$, Muh. Rosyid Ridlo ${ }^{2}$ \\ Program Studi Sosiologi Fakultas Ilmu Sosial dan Politik \\ Universitas Sebelas Maret Surakarta Indonesia \\ Email $^{1}: \operatorname{rovad} 33 @$ student.uns.ac.id, Email $^{2}$ : muhrosyid@staff.uns.ac.id
}

\begin{abstract}
Nationalism is a form of expression of the love of citizens in the country's homeland. Today many young generations start to fade the soul of its nationalism so researchers want to know how the institution of boarding schools implanted nationalism to the students. This research took location in Sunan Gunungjati Ba'alawy Boarding School, Gunungpati, Semarang. The theory used in this study was the action theory put forward by Max Weber. This type of research is case studies, data is taken with in-depth interview techniques, observations, and documentation. Researcher use purposive sampling techniques and to ensure the validity of the used data triangulation source. From the results of the study can be concluded that the strategi of Sunan Gunung Jati Ba'alawy Boarding School in instilling nationalism is done with daily activities conducted by students, such as when living in the hut, to do something inside the hut. Through the activities of the week and every month, such as Roan, grave pilgrimage, study, Khitobah, and so forth. And also annual activities, such as activities on Islamic holidays, the Prophet's mawlid days, to the agenda activities of the country. Some factors that support among them are the concern of the surrounding community, teachers who can always be an example, the enthusiasm of students, and also good relations with the TNI and Police. But there are some things that become barriers, such as natural condition, students who had less sensitive to the surrounding. The implementation of this research will be expected to be a good example of other formal and non-formal education in cultivating nationalism to the younger generation.
\end{abstract}

Keywords: Strategy, Nationalism Internalizing, Boarding School..

\begin{abstract}
Abstrak: Nasionalisme adalah salah satu bentuk ungkapan perasaan cinta para warga Negara terhadap tanah airnya. Dewasa ini banyak generasi muda yang mulai memudar jiwa nasionalismenya sehingga peneliti ingin mengetahui bagaimana lembaga pendidikan pondok pesantren menanamkan nasionalisme kepada para santri. Penelitian ini mengambil lokasi di Pondok Pesantren Sunan Gunungjati Ba'alawy, Gunungpati, Semarang. Teori yang digunakan dalam penelitian ini adalah teori aksi yang dikemukakan oleh Max Weber. Jenis penelitian ini adalah Studi Kasus, data diambil dengan teknik wawancara mendalam, observasi, dan dokumentasi. Sampel diambil dengan teknik purposive sampling dan validitas data dengan triangulasi sumber. Dari hasil penelitian dapat disimpulkan bahwa strategi Pondok Pesantren Sunan Gunung Jati Ba'alawy dalam menanamkan nasionalisme dilakukan dengan kegiatan harian santri, seperti saat hidup dalam pondok, saat mengerjakan sesuatu didalam pondok. Melalui kegiatan rutinan tiap minggu dan tiap bulan, seperti adanya kegiatan roan, ziarah kubur, pengajian, khitobah, dan lain sebagainya. Dan juga kegiatan tahunan, baik secara kegamaan maupun secara nasional, seperti adanya kegiatan di hari raya islam, peringatan maulid nabi, hingga kegiatan agenda negara, seperti upacara bendera 17
\end{abstract}


Agustus. Beberapa faktor yang mendukung diantaranya adalah kepedulian masyarakat sekitar, guru yang selalu bisa menjadi contoh, antusiasme santri, dan juga hubungan baik dengan perangkat negara, seperti dengan TNI maupun POLRI. Namun ada beberapa hal yang menjadi penghambat, salah beberapa diantaranya adalah kondisi alam yang terlampau nyaman, beberapa santri yang masih memiliki rasa kurang peka terhadap sekitar, dan juga peraturan yang kurang begitu mengikat para santri. Implementasi dari penelitian ini diharapkan menjadi contoh bagi pendidikan formal maupun non-formal dalam menanamkan nasionalisme.

Kata kunci: Nasionalisme, Strategi Penanaman, Pondok Pesantren.

\section{PENDAHULUAN}

Nasionalisme adalah salah satu bentuk ungkapan perasaan cinta para warga Negara terhadap tanah airnya. Dengan adanya rasa cinta itulah yang nantinya akan mengembangkan rasa persatuan dan kesatuan pada negara tersebut. Sebuah negara tidak akan mampu mempertahankan persatuan dan kesatuannya jika tidak dilandasi oleh jiwa nasionalisme warga negaranya. Generasi muda adalah salah satu generasi yang menjadi penerus kelangsungan hidup bangsanya dimasa depan, maka itu adalah asset negara yang harus selalu dibimbing dan juga dijaga. Terlebih lagi jika sudah menyentuk masalah ideologi, jangan sampai mereka melupakan akan ideologi bagsa mereka sendiri dan ikut dalam jajahan ideologi negara asing yang selalu masuk. Jika dilihat pada jaman sekarang ini, maka tidak menutup kemungkinan bahwa jiwa nasionalisme rakyat ini sedang dijajah oleh pihak luar. Mulai dari adanya arus globalisasi yang menjadikan dunia serasa semakin sempit karena mudahnya mengakses berbagai informasi dengan bermacam cara, dan contohnya adalah dengan teknologi internet. Globalisasi tersebut tidak lepas juga dengan semakin majunya sebuah tehnologi.

Salah satu contoh kasus tentang semakin memudarnya rasa nasionalisme para generasi sekarang adalah, bagaiamana mereka menyikapi sebuah kasus yang berkaitan dengan isu agama, dan sekarang ini isu politikpun seakan ikut menjadikan gejolak perpecahan semakin besar. Seperti pada saat awal gejolak tentang penistaan agama pada akhir 2017 silam, yang sampai sekarang gerakan itu masih tetep terlihat, ditambah gerakan keinginan untuk menjadikan negara Indonesia menjadi negara khilafah oleh beberapa golongan, hingga saat ini isu politik yang semakin membuat Indonesia seolah menjadi 2 bagian. Dalam melihat hal tersebut maka peneliti ingin mencari tahu bagaimana sebuah proses peanaman nasionailsime khususnya di dalam pondok pesantren, tepatnya Pondok Pesantren Sunan Gunungjati Ba'alawy, Semarang.

Weber menggunakan konsep rasionalitas dalam klasifikasinya mengenai tipe- tipe tindakan . Menurut Max Weber, tindakan rasional adalah tindakan manusia yang dapat mempengaruhi individu-individu lain dalam masyarakat. Weber membagi tindakan rasional ini kepada empat jenis atau bentuk. Pertama ialah tindakan rasional instrumental yaitu tindakan yang diarahkan secara rasional untuk mencapai sesuatu tujuan yang tertentu. Kedua ialah tindakan rasional nilai yaitu tindakan yang akan ditentukan oleh pertimbanganpertimbangan atas dasar keyakinan seseorangindividu terhadap nilai -nilai estetika, etika atau keagamaan. Ketiga ialah tindakan emosional yaitu segala tindakan seseorang individu yang akan dipengaruhi oleh perasaan dan emosi. Jenis atau bentuk tindakan terakhir yang 
dinyatakan oleh Max Weber ialah tindakan tradisonal yaitu tindakan di mana seseorang akan melakukan suatu tindakan hanya karena mengikuti amalan tradisi atau kebiasaan yang telah berlaku. Menurut Max Weber, tindakan social merupakan tindakan individu sepanjang tindakan itu ilakukan untuk orang lain yang mempunyai makna dan arti subyektif atas tindakan yang sudah dilakukannya. Suatu tindakan social tidak dapat dikatakan sebagai tindakan social jika diarahkan kepada benda mati, namun akan dikatakan sebagi tindakan social karena memang benar-benar ditujukan untuk orang lain.

\section{METODE PENELITIAN}

Penelitian dilakukan di Pondok Pesantren Sunan Gunungjati Ba'alawy, Gunungpati, Semarang. Penelitian ini bertujuan untuk mengetahui strategi yang dilakukan oleh Pondok Pesantren Sunan Gunungjati Ba'alawy (SGJB), Gunungpati, Semarang dalam penanaman jiwa nasionalisme kepada para santrinya. Penelitian ini juga bertujuan untuk mengetahui kendala yang dihadapi pada saat pelaksanaan strategi serta pendukung yang menunjang strategi tersebut dilaksanakan. Jangka waktu yang dibutuhkan untuk penelitian ini selama 4 bulan terhitung sejak agustus sampai dengan November 2018.

Dalam perencanaan dan kegiatan penelitian, maka penulis dapat simpulkan beberapa hal yaitu sebagai berikut:

1. Penelitian ini adalah penelitian dalam bentuk metode kualitatif dengan pendekatan studi kasus.

2. Tekhnik dalam pengambilan sampel sendiri menggunakan teknik purposive sampling dengan memilih informan yang dianggap kredibel dan relevan, yang nantinya akan dilanjutkan dengan teknik wawanara mendalam, baik secara formal maupun non formal sehingga mendapatkan data yang valid, yakni Pengasuh pondok, Guru, dan Santri, dan dilengkapi dengan data sekunder berupa data dokumen dari pondok, dari website pondok, dan juga dokumentasi.

3. Untuk mendapatkan data yang semakiin valid, maka dipakai teknik validitas data dengan trianggulasi data. Sedangkan teknis analisis data menggunakan teknis analisis interaktif yang dimulai dari pengumpulan data, pengolahan data, reduksi data, penyajian data, dan penarikan kesimpulan.

\section{HASIL DAN PEMBAHASAN}

Dari hasil penelitian dapat disimpulkan bahwa strategi Pondok Pesantren SGJB dalam menanamkan nasionalisme dilakukan dengan tindakan-tindakan kecil hingga yang benarbenar keigtan yang menyangkut masalah nasionalisme. Yaitu dengan kegiatan-kegiatan harian yang dilakukan oleh santri, seperti saat hidup dalam pondok, saat mengerjakan sesuatu didalam pondok. Melalui kegiatan rutinan baik tiap minggu maupun tiap bulan juga, seperti adanya kegiatan roan, ziarah kubur, pengajian, khitobah, dan lain sebagainya. Dan juga kegiatan tahunan, baik secara kegamaan maupun secara nasional, seperti adanya kegiatan di hari raya islam, peringatan maulid nabi, hingga kegiatan agenda negara, seperti upacara bendera 17 Agustus hingga acara lainnya.

\section{Arti Penting Nasionalisme Bagi Pondok Pesantren Sunan Gunungjati Ba'alawy.}

Civitas akademika pondok pesantren sunan gunungjati Ba'alawy memahami nasionalisme itu sangatlah penting, mereka memahami bahwa mereka ada karena para pendahulu mereka ada terlebih dahulu. Mereka juga sangat enggan untuk melupakan 
bagaimana sejarah perjuangan para pahlawan memperebutkan kemerdekaan dari para penjajah asing. Mereka menilai nasionalisme, rasa cinta tanah air itu tidak melulu mengenai berperang mengangkat senjata melawan musuh-musuh yang ada. Nasionalisme dalam skala kecil bisa juga dilakukan, karena setiap elemen masyarakat mempunyai porsi, dan tugas untuk mencintai tanah airnya secara berbeda-beda sesuai dengan porsinya. Jati diri bangsa harus tetap dijaga, mencintai produk dalam negeri adalah hal kecil yang bisa dilakukan untuk mewujudkan rasa cinta terhadap Negara kita.

\section{Strategi Penanaman Nasionalisme Pada Santri.}

- Penanaman secara Non-Formal

Sejumlah tindakan penanaman nasionalisme yang merupakan tindakan nonformal yang dilakukan oleh pondok, dalam hal ini tujuannya tetaplah menjaga nasionalisme tanpa memberikan kesan yang berat kepada yang menanamkan maupun yang akan ditanamkan kepadanya kecintaan pada tanah air.beberapa hal yang dilakukan dalam memberikan cinta negara kepada santri antara lain adalah sebagai berikut:

1) Khaul

Khaul sendiri berasal dari Bahasa arab yang artinya tahunan. Khaul adalah sebuah acara peringatan yang diadakan setiap tahunnya, biasanya diadakan untuk memperingati hari kematian seseorang, mulai dari keluarga, kyai, wali, syaikh, maupun habaib. Peringatan tersebut berwujud dalam sebuah rangkaian acara yang didalamnya adalah kumpulan beberapa doa, yang dimana doa tersebut yang ditujukan untuk beliau yang sudah meninggal dunia.

2) Penanaman dalam kegiatan keseharian santri

Dalam pondok pesantren Sunan Gunungjati Ba'alawi ini, para santri diajarkan bagaimana mencintai tanah air dengan porsi yang sewajarnya. Sepeti contoh hal yang bisa dilakukan adalah dengan Gotong royong.

3) Ziarah Kubur

Ziarah kubur ini dilakukan pada setiap hari Ahad, sesudah ngaji sehabis sholat Shubuh. Ziarah ini dilakukan makam yang berada dikawasan pondok pesantren, dan guna daripada ziarah ini selain fungsi keagamaan sebagai pengingat kematian kita kelak, juga sebagai rasa hormat kita kepada pendahulu kita, rasa terima kasih kita dengan mereka dengan mengirimkan doa.

4) Penanaman Solidaritas Kepada Santri

Mereka ditempatkan disatu tempat yang sama, dalam hal tidur misalnya, satu kamar bisa berisi 7 sampai dengan 15 anak setiap kamarnya. Pada saat makanpun, mereka makan tidak dengan satu piring kecil, namun dengan menggunakan nampan yang bisa digunakan untuk makan bersama-sama setidaknya 4 orang santri bisa makan bareng. Dalam penggunaan Bahasa, mayoritas yang digunakan adalah Bahasa nasional yaitu Bahasa Indonesia.

5) Selapanan selasa kliwon.

Dalam kegiatan untuk menambah wawasan keislaman, maka diadakan suatu pengajian yang dapat dihadiri oleh khalayak umum. Bukan khusus untuk santri saja, dan acara tersebut diadakan setiap hari selasa kliwon, atau malam rabu. Acara ini diadakan sebagai wujud dari syiar terhadap masyarakat setempat, dan juga menjadi salah satu ajang untuk bisa bersilaturahmi kepada masyarakat.

6) Istighosah mauled

Dalam pelaksanaan pembacaan mauled ini, beberapa acara dilakukan, mulai dari ziarah kubur, lalu membaca Manaqib, dilanjutkan untuk membaca Ratib, lalu 
masuk Muqodaman Al-Quran, dan dalam acara juga diadakan karnaval juga, atau mungkin sesekali wayangan yang merupakan salah satu kesenian yang identic dengan jawa, dimana itu dahulu digunakan oleh para wali untuk menyebarkan agama islam dengan memadukan antara budaya dengan agama.

7) Khitobah

Pembagian panitia kegiatan khitobah berdasarkan kelas masing-masing. Dan seluruh acara dilakukan oleh santri, mulai dari pemegang hadrah, menjadi pembawa acara, menjadi pejabat pemerintahan, baik itu ketua RT maupun juga kepala daerah, hingga pengisi tausiah. Semua itu dibagi per serorangan dalam satu kelas itu. Dapat dikatakan bahwa hal ini juga menjadi salah satu cara untuk menanamkan nasioanlisme kepada santri, dengan cara mengajari mereka untuk membuat acara, menjadi pemimpin desa, maupun juga menjadi tokoh keagamaan dalam masyarakat. Dan tak lupa juga, selalu dinyanyikan lagu kebangsaan diawal acara, yang juga didirigeni oleh santri.

8) Ratiban malem jumat

Kegiatan yang dilakukan semacam ini jua menjadi salah satu cara agar hubungan antar warga masyarakat dapat selalu terjamin dan semakin harmonis. Mencintai negara sendiri, mencintai tanah air sendiri tidak melulu tentang bagaimana kita membesar-besarkan kemampuan bangsa kita dimata dunia. Namun bisa dimulai dari hal kecil, seperti menjaga kesatuan dan persatuan negara melalui element terkecilnya terlebih dahulu, yaitu masyarakat setempat.

- Penanaman Nasionalisme Secara Formal

1) Bela Negara SMK

Kegiatan ini berupa praktek PBB dan Paskibraka. Dalam pembimbingan dua hal tersebut, kadangkala dari pihak pondok pesantren mendatangkan instansi pemerintahan, seperti koramil ataupun polisi untuk membantu melatih para siswa SMK kelas 11 ini. Dalam setiap kegiatan yang ada dikecamatan, maupun kota, seringkali dari Pondok mengirimkan timnya untuk ikut serta dalam acara, seperti saat ada pawai, atau bahkan ada acara kenegaraan.

2) Cerita Tentang Sejarah

Menceritakan sejarah yang disisipkan disela-sela pengajian keagamaan ini bertujuan juga untuk selalu mengingat dan menanamkan bagaimana sejarah bangsa Indonesia ini lahir dan lolos dari penjajahan negara asing, bagaimana perjuangan para pahlawan, dan juga para santri dalam membela kesatuan negara republic Indonesia.

3) Menjalin Hubungan dengan Setiap Elemen Negara

Pondok pesantren sering untuk mengundang para pejabat pemerintahan, TNI, dan Polisi. Disisi lain, pada saat masyarakat mempunyai hajat/acara dikampung mereka juga tidak jarang untuk mengundang dan melibatkan pondok dalam acara itu. Bahkan dari luar masyarakat setempat juga begitu, seperti halnya saat kecamatan atau bahkan kota semarang memperingati hari besar nasional, maka seringkali pihak pondok mengirimkan delegasi untuk mengikuti serangkaian acaranya, dan bisa juga justru dari pihak kecamaatan kota yang sengaja untuk mengundang pondok pesantren, paling tidak mengikuti pawai, atau juga bisa untuk menjadi petugas pengibar bendera.

4) Ikut memperingati hari besar nasional

Dalam setiap kegiatan yang dilakukan oleh pondok pesantren, mereka tidak mengesampingkan dengan adanya hari besar nasional. Entah dari segi keagamaan, seperti Hari Santri Nasional, dan Hari Raya. Namun juga hari besar kebangsaan, 
seperti Hari Kartini, Hari Kemerdekaan, Hari Pendidikan, dan lain sebagainya. Mereka setiap datang hari besar nasional, akan mengadakan suatu peringatan untuk menjaga sejarah dan menghormati jasa-jasa para pahlawan yang telah gugur mendahului kita semua.

\section{Faktor Pendorong Dan Penghambat}

a. Faktor Pendukung

1) Letak Pondok yang berada diantara warga yang agamis

Antara masyarakat setempat dan pondok bisa dikatakan memiliki ikatan yang harmonis, mereka saling dukung satu sama lain. Kalau saja dipondok memiliki suatu hajatan atau acara, pondok mengiikutsertakan warganya dalam acara itu. Pun sebaliknya, jikalau saja masyarakat memiliki hajatan atau acara dikampung, mereka juga tidak segan untuk mengikutsertakan para santri ataupun pengurus dari pondok pesantren Sunan Gunungjati Ba'alawi. Dengan terciptanya hubungan yang harmonis tersebut, bisa dikarenakan karena latar belakang masyarakatnya yang memang sudah agamis, dipadukan dengan pondok pesantren yang notabennya adalah pendidikan bernuansa keagamaan.

2) Ketertarikan santri terhadap kegiatan yang diadakan pondok

Santri dikatakan cukup berantusias dalam mengikuti setiap kegiatan yang ada didalam pondok pesantren Sunan Gunungjati Ba;alawi ini. Mereka akan segera melakukan apa yang harus dilakukan saat sudah waktunya. Seperti saat ada acara upacara bendera disetiap hari senin, upacara kenegaraan pada 17 Agustus, maupun acara-acara lomba dan juga karnaval. Dan tidak ketinggalan acara pengajian dan pembacaan kitab dihari-hari tertentu, mereka akan segera menempatkan diri dan menjalankan tugas mereka masing-masing. Semua kegiatan ini pastilah melibatkan banyak santri, dan mereka akan selalu berbondong-bondong dan bersama-sama untuk melakukan pekerjaan yang memang sudah ditugaskan kepada mereka.

3) Dukungan dari masyarakat

Masyarakat yang ada disana jauh sebelum pondok pesantren ini berdiri Alhamdulillah mendukung sebagian besar, bahkan setiap kegiatan-kegiatan yang dilakukan oleh pondok pesantren Sunan Gunungjati Ba'alawi. Hal tersebut pastilah karena hubungan antara pondok dengan lingkungan masyarakat setempat itu selalu dijaga agar tetap harmonis. Menjaga silaturahmi dengan melakukan hal-hal sederhana, seperti saling mengundang satu sama lain saat masing-masing memiliki hajatan atau acara.

4) Besarnya Loyalitas Guru/Kyai dan juga Loyalitas Santri kepada Kyainya.

Salah satu guru yang mengajar dipondok pesantren Sunan Gunungjati Ba'alawi mengatakan bahwa Kyai Masroni sangat loyal. Beliau adalah salah satu orang yang sangat ia segani. Loyalitas Romo Kyai kepada gurunya menjadi salah satu faktor yang mendukung dalam proses penanaman nasionalisme kepada para santrinya. Jika kepada guruny saja sudah memiliki loyalitas, maka dengan negaranya pun pasti juga akan menjadi loyal, apalagi Guru beliau adalah orang yang memiliki jiwa nasionalisme yang tinggi pula, tentu itu akan menjadikan nilai lebih lagi dalam hal nasionalisme. 
b. Faktor Penghambat

1) Santri Tidak Taat Peraturan.

Dalam hal peraturan tersebut, didalam pondok ini termasuk sebuah peraturan yang tidak begitu padat dan mengikat seperti pondok-pondok lainnya. Beberapa hal yang mungkin saja tidak diperbolehkan dilakukan oleh pondok lain, disini boleh saja dilakukan. Namun hal itu juga tidak tanpa pengawasan dari guru/ustad yang mengampu dipondok tersebut. Salah satunya adalah peraturan tentang penggunaan gadget atau handphone.

2) Letak Pondok dan juga kondisi alam yang tidak bisa dikontrol.

Dengan kondisi alam yang sangat sejuk dan nyaman itulah yang kadang menjadi boomerang bagi para santri dalam mengikuti kegiatan yang ada di pondok pesantren tersebut, kalau saat memang kondisi sangat mendukung untuk berdiam diri didalam kamar misalnya, walaupun sebenarnya juga ada kegiatan diluar, mereka akan cenderung untuk berada dikamar saja.

3) Kurang baiknya management waktu bagi beberapa santri

Terutama bagi santri yang sudah memasuki dunia perkuliahan. Mereka tentunya akan lebih dekat dengan organisasi diluar pondok, yang mereka ikuti. Dan tentu saja ini akan menguras tenaga dan pikiran mereka, karena selain memikirkan bagaimana keadaan perkuliahan dan pesantren, mereka mau tidak mau juga harus memikirkan bagaimana untuk menjalani setiap program kerja dari kegiatan mereka dengan oraganisasi lain.

4) Pemikiran masyarakat yang kurang percaya kepada pondok pesantren

Masyarakat beranggapan bahwa pendidikan pesantren itu kuno dan ketinggalan zaman. Beberapa orang beranggapan juga bahwa jika seseorang masuk pesantren, maka memang benar kalau dia akan pandai dalam hal agama, namun kurang dalam hal kemasyarakatan.

5) Kurangnya perhatian dari pemerintah

Dengan latar belakang keagamaan, pondok pesantren sekarang ini dapat dikatakan kurang mendapatkan perhatian dan dukungan dari pemerintah. Berbeda dengan beberapa pendidikan formal yang memang disediakan oleh pemerintah. Padahal pondok pesantren juga dapat memberikan kontribusi yang cukup besar pada negara, terlebih saat masih dalam masa perjuangan melawan penjajah.

Menurut Max Weber, tindakan sosial dapat digolongkan menjadi empat kelompok (tipe) untuk menjelaskan makna tindakan yang dibedakan dalam konteks motif para pelakunya, yaitu tindakan rasional instrumental, tindakan rasional berorientasi nilai, tindakan tradisional, dan tindakan afektif. Tindakan pertama adalah tindakan rasional instrumental, yaitu adalah sebuah tindakan yang dilakukan oleh seseorang dengan memperhitungkan antara cara yang akan digunakan dengan tujuan yang akan dicapai dengan menggunakan ketersediaan alat yang ada. Dalam kasus ini, pondok pesantren Sunan Gunungjati Ba'alawi menerapkan tujuan untuk selalu menanamkan rasa nasionalisme agar para pendahulu mereka akan selalu dikenang dan tidak dilupakan behgitu saja.

Disisi lain, mereka juga menolak lupa bahwa sejarah Indonesia juga tidak luput dari jasa para kyai dan santri yang saat itu ikut berjuang dalam mempertahankan tanah ait kebangsaan. Dengan cara menanamkan selalu kepada santri yang ada didalam pondok pesantren ini maka diharapkan tujuan itu akan selalu ada dan tercapai sehingga masyarakat Indonesia khususnya para kaum muda terlebih lagi santri akan selalu mengetahui darimana mereka berasal dan bagaimana mereka sampai bisa menikmati keindahan dan ketentraman dari ancaman penjajah. Setidaknya mereka mengetahui sejarah bangsa Indonesia, sejarah 
perjuangan dan nantinya diharapkan mereka mampu menyikapi hal-hal tersebut. Dengan media berupa kegiatan-kegiatan harian, mingguan, bulanan, maupun agenda tahunan, mereka menyampaikan dan menanamkan rasa nasionalisme. Baik dengan cerita tentang sejarah negara, sejarah perjuangan para pahlawan, hingga mereka adakan kegiatan yang tidak berbau agamis seperti halya peringatan-peringatan hari besar nasional. Namun sebagai basis dari pondok pesantren, kegiatan keagamaan juga tidak lupu menjadi alat untuk menjaga nasionalisme.

Tindakan yang kedua adalah Tindakan rasionalitas nilai yang memiliki sifat bahwa alat-alat yang digunakan hanya merupakan pertimbangan atau perhitungan yang sadar, sementara tujuan-tujuannya sudah ada didalam hubungannya denga nilai-nilai individu yang bersifat absolut. Tindakan ini bersifat rasional dan memperhitungkan manfaatnya, tetapi tujuan yang hendak dicapai tidak terlalu dipentingkan oleh si pelaku. Pelaku hanya beranggapan bahwa yang paling penting tindakan itu termasuk dalam kriteria baik dan benar menurut ukuran dan penilaian masyarakat di sekitarnya. Dalam tindakan ini yang dilakukan oleh pondok pesantren Sunan Gunungjati Ba'alawi adalah dengan mengadakan kegiatankegiatan yang dimana didalamnya memiliki kandungan nilai yang tersirat sebagai bentuk dari tujuan yang ingin dicapai dalam kegiatan itu. Salah diantaranya adalah adanya kegiatan harian yang diantaranya dengan pendidikan makan bersama, hal ini bermanfaat untuk menjadikan santri saling kenal dan dekat dengan santri lainnya sehingga mencipatakan perdamaian yang dasar, dan menghindarka dari perpecahan.

Disisi lain juga tindakan ini bisa menjadi salah satu cara untuk mempertahankan kesatuan dan persatuan negara kesatuan republic Indonesia. Dan makan bersama dengan piring besar atau nampan itu menjadi alat untuk mencapai tujuan dari pondok pesantren dalam menyatukan sesame santri tanpa pandang latar belakang, tanpa pandang usia, tanpa pandang bulu. Kegiatan lain yang masih seirama adalah dengan tidur dengan 8-9 orang dalam satu kamar, maka hal itu lambat laun akan menjadikan mereka semakin akrab. Ditambah dengan Bahasa yang digunakan adalah Bahasa nasional, yaitu Bahasa Indonesia, sehingga tidak menjadikan permasalahan yang begitu besar karena mereka berasal dari berbagai daerah yang berbeda-beda.

Dari tindakan yang kecil hingga tindakan yang besar yang dilakukan oleh pondok untuk dapat menamkan jiwa nasionalisme pada santri, bisa dengan pendidikan yang diadakan setiap berapa hari dalam seminggu atau sebulan. Misalnya adalah upacara bendera setiap hari senin. Sangat jelas bahwa tindakan ini mempunyai tujuan untuk menanamkan nasionalisme pada santri, upacara inin selalu dilakukan didalam kawasan pondok sendiri.

Juga ada kegiatan yang namanaya roan, yaitu tindakan gotong royong yang dilakukan oleh seluruh civitas akedemika pondok tanpa pandang siapa mereka, tindakan ini terwujud dalam rangka membersihkan area pondok, dan dilakukan setiap hari minggu. Sikap gotong royong meruapakan tujuan yang akan dicapai untuk menjadi wujud cinta tanah air, dan tindakan ini disaranai dengan roan membersihkan pondok. Sebelum roan, terlebih dahulu mereka pergi kekuburan untuk berziarah, selain untuk mengigatkan kematian, dan mendoakan, mereka juga diajarkan untuk menghormati dan mengenang jasa-jasa orang yang telah mendahului mereka, karena tidak perlu melulu tentang perang, namun dengan membersihkan area makam, itu sudah menunjukan kalau mereka berbakti kepada pendahulu mereka. Dan setiap ada sebuah pengajian baik secara mingguan, bulanan, ataupun tahunan, mereka selalu menyanyikan lagu Indonesia raya, yang dimana itu jarang dilakukan bahkan oleh lembaga pendidikan formal sekalipun. Tujuan yang akan dicapai tentulah tentang penanaman nasionalisme kepada jamaah khususnya santri pondok pesantren itu. 
Bahkan dalam pendidikan formal, yaitu di SMK Sunan Gunungjati Ba'alawi, terdapat jurusan yang berkaitan dengan penanaman nasionalisme, yaitu bela negara. Tindakan nyata yang ada adalah mereka ada yang namanya pasukan paskibraka, yang cukup sering untuk diundang dalam acara-acara kebangsaan dikecamatan maupun dikota. Sangat jelas tujuan apa yang ingin dicapai dan dengan cara ini juga mereka menanmkan nasionalisme itu kepada santri mereka. Dalam pelatihan paskibra itu, mereka mendatangkan langsung pelatihnya dari pihak koramil maupun kepolisian, selain untuk mendidik dan mengajari tentang paskibraka, mereka juga menyisipkan tujuan lain yaitu berupa silaturahmi kepada para umara sebagai wujud kepercayaan mereka terhadap instansi pemerintahan. Kepercayaan itu salah satu wujud cinta tanah air yang sederhana bagi para santri. Dalam menyambung silatuhami dengan para umara, pihak pondok tidak jarang mengundang pihakk pemerintahan untuk selalu hadir dalam acara yang ada dipondok, baik acara kecil maupun acara akbar, dan yang pasti mereka akan mengundang kepolisian dan isntansi pemerintah lainnya saat upacara hari besar nasional, salah satu contohnya adalah pada 17 Agustus.

Tindakan ketiga yang diungkapkan oleh Webber adalah tindakan afektif, yang dimana tindakan ini sebagian besar dikuasai oleh perasaan atau emosi tanpa pertimbanganpertimbangan akal budi. Seringkali tindakan ini dilakukan tanpa perencanaan matang dan tanpa kesadaran penuh. Jadi dapat dikatakan sebagai reaksi spontan atas suatu peristiwa. Tindakan yang ditentukan oleh kondisi emosi aktor. Ledakan kemarahan seseorang misalnya. Atau ungkapan rasa cinta, kasihan, adalah contoh dari tindakan afektif ini. Tidak banyak ditemukan oleh peneliti tentang tindakan ini, namun peneliti menemukan salah satu hal yang bisa dikatakan merupakan tindakan afektif, yaitu cinta santri kepada romo kyai Masroni, mereka akan sangat andap asor jika berada diantara rama kyai, dan ketika selesai acara, maka para santri akan sabar menunggu kyai untuk meninggalkan tempatnya terlebih dahulu. Contoh kasus lain adalah, saat ada anak yang berada dipinggir jalan, ya bisa dikatakan anak jalanan, pernah salah seorang guru yang ada mengajar dipondok itu mengajaknya untuk kepondok dan dia dijadikan santri disana. Hal itu dilakukan bisa juga karena simpati dan kasihan terhadap anak itu.

Tindakan terakhir adalah tindakan tradisional, yang merupakan sebuah tindakan yang tidak rasional karena hanya berorientasi kepada tradisi masa lampau. Seseorang melakukan tindakan hanya karena kebiasaan yang berlaku dalam masyarakat tanpa menyadari alasannya atau membuat perencanaan terlebih dahulu mengenai tujuan dan cara yang akan dipakai. Dan tindakan yang semacam ini tidak diketemukan oleh peneliti dipondok pesantren Sunan Gunungjati Ba'alawi. Semua kegiatan yang ada dipondok pesantren ini belandaskan tujuan dan banyak yang menggunakan perencanaan terlebih dahulu. Terlebih lagi kegiatan besar dalam suatu acara tahunan, semacam maulidan dan juga hari raya. Setiap ada pihak luar yang mau mengadakan acara dengan pondokpun juga direncanakan terlebih dahulu. Bahkan ketika ada peringatan 17 Agustus, maka kelas SMK pun diliburkan dan diganti dengan kegiatan latihan paskibra untuk mensukseskan acara peringatan hari kemerdekaan negara kesatuan republic Indonesia ini. Acara harian, seperti membaca kitabpun juga pastilah berorientasi tujuan, setidaknya adalah mencari ilmu dan mengharapkan ridho Allah SWT.

\section{KESIMPULAN}

Dalam kehidupan sekarang ini, sangat disayangkan jika ada beberapa isu yang menyebar tentang bagaimana bergejolaknya negara kita, tentang adanya kasus-kasus yang menggemparkan seluruh Indonesia. Mulai dari semakin renggangnya hubungan antar suku atau kelompok. Tentang perpecahan yang kian menjadi, dan faktor-faktor lain yang membuat negara kita semakin terlihat kehilangan jati dirinya. Itulah landasan juga mengapa kyai 
pondok pesantren Sunan Gunungjati Ba'alawi menerapkan tentang nasionalisme pada sistem pengajaran dipondok tersebut. Mereka berharap dengan berada dipondok dan mengetahui tentang nasionalisme, maka kelak mereka akan menjadi pribadi yang bisa bermanfaat bagi dirinya, keluarganya, lingkungan, agama, dan juga negara ini. Bukan justru sebaliknya, yang semakin menggerus nilai-nilai nasionalisme negaranya, tempat dimana dia dilahirkan dan mereka pijak.

Dalam menanamkan nasionalisme, pondok pesantren ini menggunakan internalisasi nilai dalam kehidupan sehari-hari. Muali dari hal-hal kecil yang bisa dilakukan oleh santri, dan tidak perlu dengan tindakan-tindakan yang begitu besar untuk dapat membela negara kesatuan republik Indonesia ini. Dalam kegiatann pondok pesantren, mulai dari kegiatankegiatan harian seperti kegiatan gotong-royong atau biasa disebut roan, juga tentang pengertian-pengertian perkara solidaritas yang ditanamkan dengan hal-hal seperti makan bersama dalam satu nampan, tidur bersama dalam satu kamar yang terdiri daria 8 orang, mengadakan kegiatan juga selalu bersama-sama, ziarah kubur sebagai pengingat jasa para pahlawan yang memperjuangkan bangsa dan negara dari penjajah. Kegitan pengajian seperti adanya pengajian setiap selasa kliwon, pengajian mauled, dan pegajian-pengajian lain selalu menyanyikan lagu kebangsaan negara republik Indonesia, dan juga menyelipkan beberapa kisah tentang negara Indonesia dan sejarah perjuangan para pahlawan kita. Bahkan saat ngaji kitab, para guru/kyai juga menyematkan cerita tentang nasionalisme.

Selanjutnya juga dalam kegiatan di SMK Sunan Gunungjati Ba'alawi, mereka mempunyai program khusus yakni bela Negara. Program itu meruapakan salah satu contoh nyata pondok pesantren yang menanamkan nasionalisme kepada santrinya. Setiap hari senin, diadakan kegiatan upacara bendera, dan disetiap hari besar juga diadakan upacara seperti pada saat 17 Agustus. Dikegiatan SMK juga, mereka ada program wajib yakni paskibraka yang diikuti oleh siswa kelas $\mathrm{X}$ dan XI. Juga diajarkan untuk menggunakan dan mengembangkan produk-produk dalam negeri, dan dalam pondok itu yang diterapan adalah dalam hal penanaman dan peternakan, mereka berusaha mengembangkan tanaman local. Dalam pelaksanaan pelatihan paskibraka tersebut, mereka turut mengundang dari instansi pemerintahan, yaitu dari polri dan tentara. Mereka juga mengajak umaraa untuk saling menjalin silaturahmi kepada pemerintahan Negara, guna mendukung program dari pemerintah juga, selain menanmkan secara internal dari pondok kepada santri mereka itu sendiri.

\section{DAFTAR PUSTAKA}

Sugiyono. 2014. Memahami Penelitian Kualitatif. Bandung: Alfabeta.

K Yim, Robert. 2005. Studi Kasus Desain dan Metode. Rajagrafindo Persada

Creswell, John W. 2016. Research Design Pendekatan Kualitatif, Kuantitatif, dan Campuran.Yogyakarta: Pustaka Pelajar.

Doyle Paul Jhonon. 1986. Teori Sosiologi Klasik dan Modern. Jakarta: Gramedia.

Moleong, J. Lexy. 2004. Metode Penelitian Kualitatif. Jakarta: Rosda Karya.

Soekanto, Soerjono. 1994. Sosiologi Suatu Pengantar. Jakarta : PT. Raja Grafindo Persada.

Thomas J. Conners, Mason C.Hoadley, Frank Dhont, Kevin Ko. 2012. Pancasila's Contemporary Appeal: Re-legitimizing Indonesia's Founding Ethos Sastra Dharma university Press.

Yatim, Badri. 1999. Soekarno, Islam, dan Nasionalisme. Jakarta. PT. Logos Wacana Ilmu

Musa, Ali Masykur. 2012. Nasionalisme di Persismpangan. Jakarta. Erlangga 
Hartono, Rudy. 2013. Bung Karno: Nasionalisme, Demokrasi, Revolusi. PT. Berdikari Nusantara Makmur.

Zaini, Hisyam dkk. 2002. Strategi Pembelajaran aktif di Perguruan Tinggi. Yogyakarta: CTSP

Slamet, Yulius. 2006. Metode Penelitian. Surakarta. Sebelas Maret University Press.

Wirawan, IB. 2012. Teori-teori dalam Tiga Paradigma. Jakarta, Kencana Prenadamedia Grup.

Sumber Jurnal

Ahmad, Zahro. 2015. Variasi Bahasa Pesantren sebagai Wujud Pergumulan Representasi Identitas Santri Mahasiswa. Yogyakarta. Universitas Islam Negeri Sunan Kalijaga.

Prabowo, Yohanes A. 2015. Studi Kasus Terhadap Pembayaran Upah Pekerja/Buruh di Kontraktor Agawe Studio Giwangan Yogyakarta. Yogyakarta. Universitas Atma Jaya.

Lay, Cornelis. 2006. Nasionalisme dan Negara Bangsa. Yogyakarta. Jurnal Ilmu dan Ilmu Politik. Volume 10

Teddy Prasetya Yuliawan \& Fathul Himam. The Grasshoper Phenomenon: Studi Kasus Terhadap Profesional yang Sering Berpindah-pindah Pekerjaan. Universitas Gajah Mada. Jurnal Psikologi. Volume 34

Binti Sholikah. 2012. Pola Kepemimpinan di Pondok Pesantren Al Muayyad Windan. Skripsi. Surakarta. Universitas Sebelas Maret.

Nurul Hikmah. 2010. Strategi Dakwah Pondok Pesantren Al-Mubarok dalam Upaya Pembinaan Keagamaan Masyarakat Sayung Demak. Fakultas Dakwah. Institut Negeri Islam Negeri Walisongo. Semarang

Sumber Internet

http://dispendukcapil.semarangkota.go.id/statistik/jumlah-penduduk-kota-semarang/2017-1220 (diakses 22 Agustus 2018, pukul 14.54 WIB)

http://www.nu.or.id/post/read/78000/imbauan-pbnu-usai-temu-kebangsaan-dengan-presidenjokowi ( diakses selasa 28 Agust 2018. Pukul 11.25 )

Instagram.com

http://www.nu.or.id/post/read/79515/kiai-said-nasionalisme-bagian-dari-iman- (diakses pada 18 Desember 2018, jam 12.30 WIB) 